
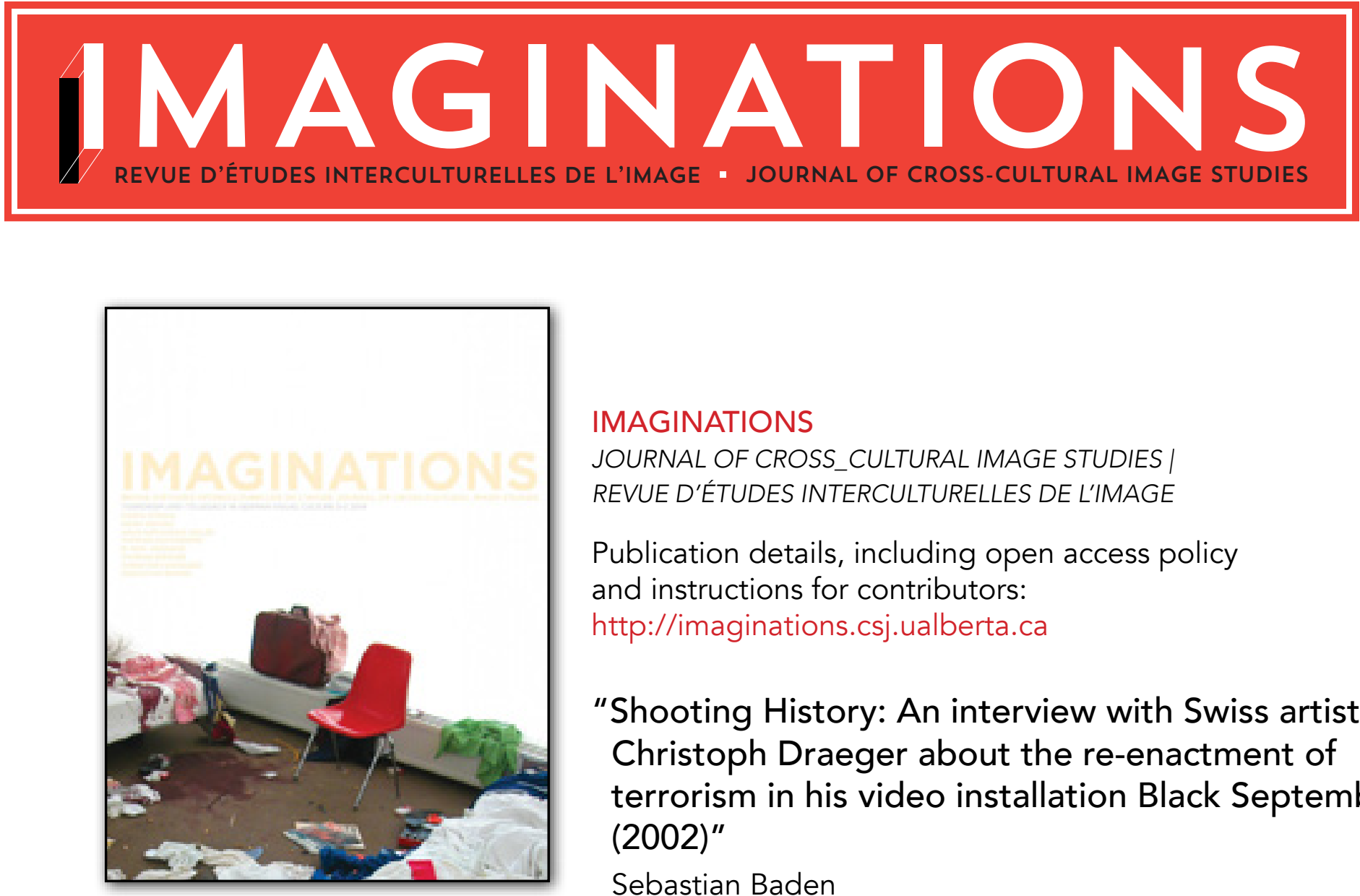

\title{
IMAGINATIONS
}

JOURNAL OF CROSS_CULTURAL IMAGE STUDIES |

REVUE D'ÉTUDES INTERCULTURELLES DE L'IMAGE

Publication details, including open access policy

and instructions for contributors:

http://imaginations.csj.ualberta.ca

\section{"Shooting History: An interview with Swiss artist Christoph Draeger about the re-enactment of terrorism in his video installation Black September (2002)"}

Sebastian Baden

October 3, 2014

To Cite this Article:

Baden, Sebastian. "Shooting History: An interview with Swiss artist Christoph Draeger about the re-enactment of terrorism in his video installation Black September (2002)" Imaginations 5:2 (2014): Web (date accessed) 120-143. DOI: 10.17742/IMAGE.TGVC.52.8

To Link to this article:

http://dx.doi.org/10.17742/IMAGE. TGVC.5-2.8

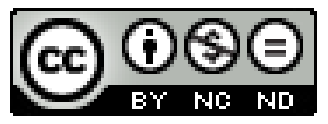

The copyright for each article belongs to the author and has been published in this journal under a Creative Commons Attribution NonCommercial NoDerivatives 3.0 license that allows others to share for non-commercial purposes the work with an acknowledgement of the work's authorship and initial publication in this journal. The content of this article represents the author's original work and any third-party content, either image or text, has been included under the Fair Dealing exception in the Canadian Copyright Act, or the author has provided the required publication permissions. 


\section{SHOOTING HISTORY: \\ AN INTERVIEW \\ WITH SWISS ARTIST \\ CHRISTOPH \\ DRAEGER ABOUT \\ THE REENACTMENT \\ OF TERRORISM \\ IN HIS VIDEO \\ INSTALLATION \\ BLACK SEPTEMBER \\ (2002)}

FIG. 1: CHRISTOPH DRAEGER, BLACK SEPTEMBER. 2002

E. Markinat we

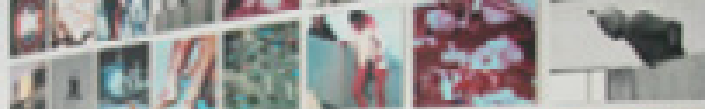

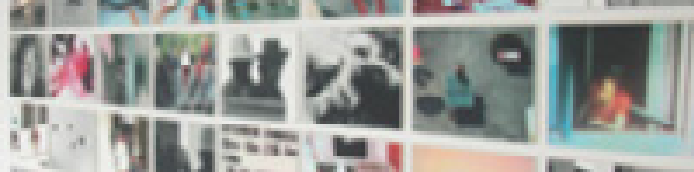
$x \sin \frac{2}{2} \frac{-2}{2}$

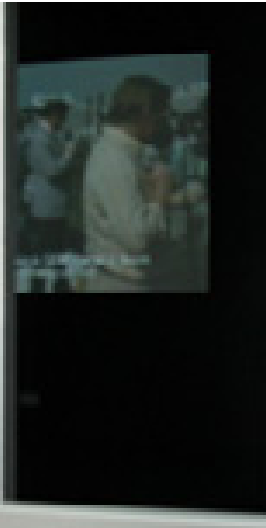




\title{
INTRODUCTION AND INTERVIEW BY SEBASTIAN BADEN
}

\author{
Skype video-interview at Universität der Bundeswehr \\ (University of the German Army), Munich, Germany, August 31, 2012
}

This contribution introduces to the video installation Black September (2002) by Swiss artist Christoph Draeger and presents statements of the artist given in an interview in 2012. Draeger collects media representations of disasters in order to reconfigure their inherent sensationalism later in his artworks. The video installation Black September consists of appropriated footage from a documentary movie and video sequences from a re-enactment of the historical events of September 5th 1972, the terrorist attack during the 20th Olympic Games in Munich. Even the artist himself gets involved in the play in his mimikry of a hostage-taker and terrorist. Thus he questions the conditions of the mutual constitution of cultural memory and collective memory. His video installation creates a "counter image" in reaction to the "omnipresent myth of terrorism", generated by the tragedy of $9 / 11$ and the media reports in its aftermath. Both terrorist attacks, in Munich 1972 and in New York 2001, mark a turning point in the visual dominance of terrorism. In the case of September 11th, the recurring images of the airplane-attacks and the explosion of the WTC, followed by its collapsing, symbolize the legacy of the "terror of attention", that would affect every spectator. The video questions the limits of the "disaster zone" in fictional reality and mass media. The artwork re-creates central scenes of the event in 1972. It brings the terrorist action close to the spectator through emersive images, but technically obtains a critical distance through its mode of reflection upon the catastrophe.The installation Black September stimulates and simulates history and memory simultaneously. It fills the void of a traumatic narrative and tries to recapture the signs that have been unknown ye
On présente ici l'installation cinématographique Black September (2002) de l'artiste suisse Christoph Draeger, accompagnée des commentaires de l'auteur recueillis lors d'un entretien donné en 2012. Draeger rassemble différentes représentations médiatiques de catastrophes dans le but de reconfigurer leur sensassionalisme dans ses oeuvres. L'installation Black September se compose de séquences d'un film documentaire et de vidéos enregistrées lors d'une reconstitution historique des événements du 5 septembre 1972, l'attaque terroriste des vingtièmes jeux olympiques à Munich. L'artiste lui-même participe à la pièce et interprète le rôle d'un preneur d'otages. Il interroge ainsi les conditions de la formation simultanée d'une mémoire culturelle et d'une mémoire collective. Son installation propose une "image à rebours » en réaction au " mythe omniprésent du terrorisme " généré par la tragédie du 11 septembre ses représentations médiatiques. Les deux attaques terroristes, de Munich en 1972 et de New York en 2001, symbolisent une victoire médiatique pour le terrorisme. Dans le cas du 11 septembre, c'est à travers la répétition des images témoignant des attaques aériennes et de l'effondrement du World Trade Center que le legs de la " terreur médiatique " s'installe. La vidéo interroge les limites de "la zone de catastrophe » dans la réalité fictionnelle et les médias de masse. L'oeuvre recrée des scènes centrales des événements de 1972. Les images entraînent les spectateurs au coeur de l'action terroriste, alors qu'en parallèle la technicité du mode de réflexion sur la catastrophe crée une distance critique. L'installation Black September stimule et simule à la fois l'histoire et la mémoire. Elle remplit les blancs d'une narration traumatique et tente de capturer des signes encore inconnus. 


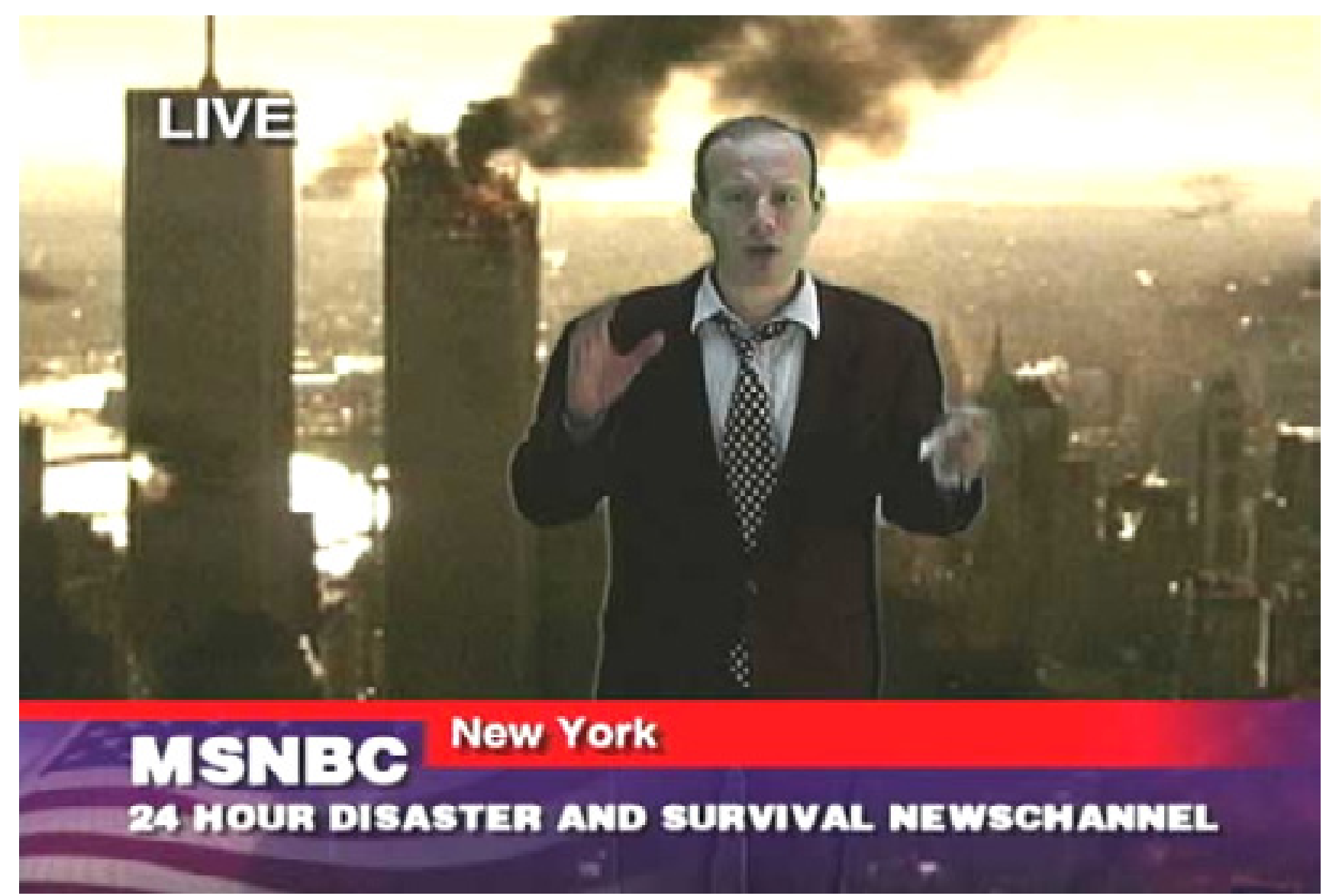

FIG. 2: CHRISTOPH DRAEGER. THE LAST NEWS. 2002.

The following skype-interview with Swiss Artist Christoph Draeger was conducted on August 31, 2012, during the 11th workshop of the German Network for Terrorism-Research (NTF) at the University of the German Army in Munich. The English translation is an abridged version of the original German-language interview. The artist talks about the production background to his video installation, Black September (2002). Draeger's artwork can be understood as a "counter image" ${ }^{1}$ created by the artist in reaction to the "omnipresent myth of terrorism" (Ammann 28), generated by the tragedy of $9 / 11$ and the media reports in its aftermath.

Since the early nineties, Draeger's work pivoted around different representations of violence, ranging from natural catastrophes to horrendous accidents and terrorist activities
(Kunstmuseum Solothurn 2003, Baden 2007a). Draeger collects media representations of these disasters in order to reconfigure their inherent sensationalism later in his artworks in photography, video, installation, or sculpture.

After the events of September 11, 2001, Draeger first created the video The Last News (2002) in cooperation with American director Reynold Reynolds and animation artist Gary Breslin and subsequently produced his video installation Black September (2002) at Roebling Hall Gallery in Brooklyn, New York. The latter was exhibited for the first time at Magnus Müller Gallery in Berlin, Germany, in September 2002.

For the video The Last News, the artist made a montage of footage from several TV news-reports about catastrophes and from 


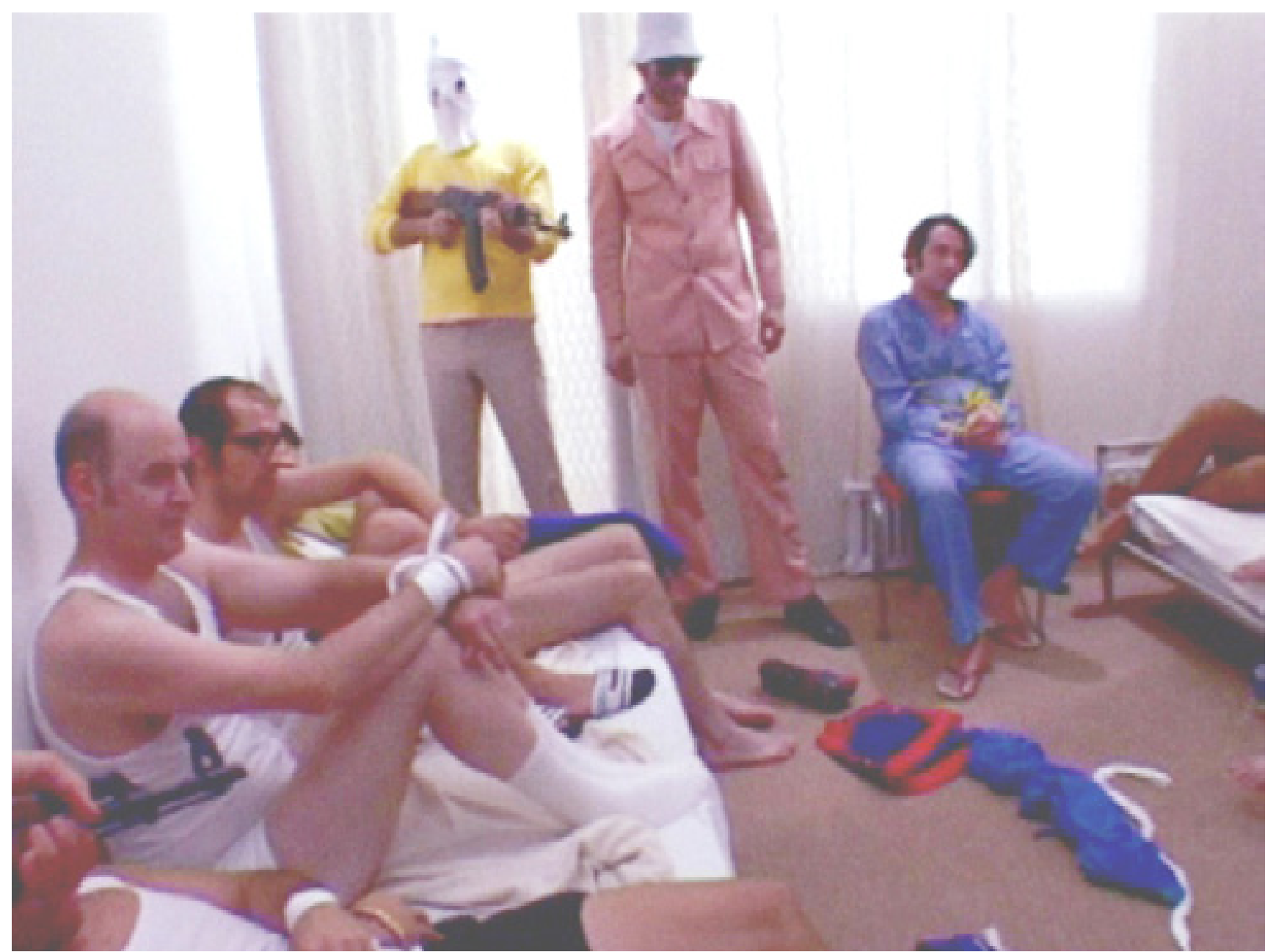

FIG. 3: CHRISTOPH DRAEGER, BLACK SEPTEMBER. 2002.

Hollywood movies such as Armageddon or Independence Day, simulating an "MSNBC 24 Disaster and Survival News Channel." ${ }^{2}$ The images include the top of Big Ben as it is being destroyed, the exploding White House, and a bird's-eye view on Paris which resembles the Ground Zero of a nuclear attack. One short sequence even shows the partially destroyed towers of World Trade Center.

Newscaster Guy Smith comments on this 'infotainment' program that runs in the background. Though all found-footage played in the back obviously is fiction, the "LIVE"broadcasting suggests real media coverage of disasters, terrorist attacks and reports on the „Operation Strikeback with Infinite Justice.” While the program is on air, several eruptions disturb the broadcasting. The explosions that were limited to their representation on the studioscreen, increasingly affect the studio itself. Finally, Smith's TV Studio seems to be totally destroyed and he collapses in front of the viewer in a nervous breakdown. Subsequently, Smith loses contact with all his correspondents worldwide and seems to be lost in chaos, to say it with Slavoj Žižek, "in the desert of the real." ${ }^{3}$ The television signal of The Last News ends in White Noise.

In this condensed 13 minute video, Draeger and Reynolds parody sensationalist newscasting through the imitation of common American news programs which combine information with entertainment. In The Last News the newscaster is both eye-witness and victim 


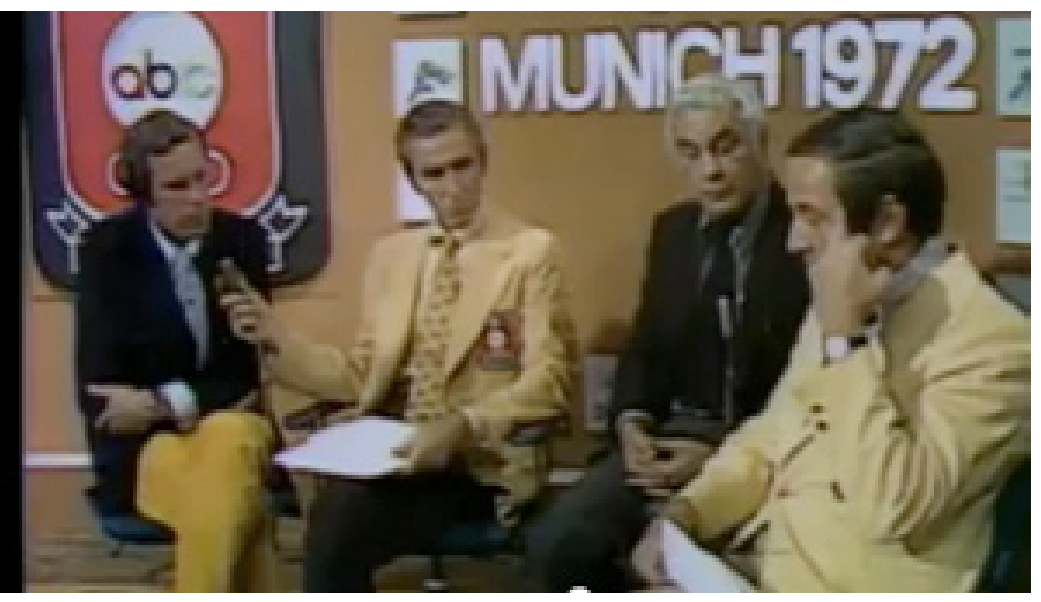

FIG. 4: CHRISTOPH DRAEGER, BLACK SEPTEMBER. 2002.

of the catastrophe he is reporting about. The video provokes various questions: How can the viewer distinguish between fictional reality and documentation? When even the 'expert' reporter is lost in terrible chaos, how is the viewer supposed to cope with bad news? Can evil transcend the safety-screen of our televisions? Where are the limits of the "disaster zone"? (Binswanger 1999: 54-61)

Following The Last News, Christoph Drager created Black September (2002), a video-installation with both appropriated footage from a documentary movie and video sequences from his re-enactment of the historical events of September 5, 1972, the terrorist attack during the 20th Olympic Games in Munich.

A group of eight Palestinians, members of the so called "Black September" group, took eleven members of the Israeli team hostage in their apartment in Connolly-Straße 31, right in the center of the Olympic Village. ${ }^{4}$ Two Israeli athletes were shot dead in the apartment. The hostage-takers demanded the release of Palestinian prisoners in Israel and the additional release of Andreas Baader and Ulrike Meinhof from German prisons, where they served their sentence for terrorist attacks. However, negotiations between the hostage- takers and the deputies of Germany and Israel were constantly delayed and deadlines postponed. Finally, late at night, during a chaotic confrontation with German Police officers at Fürstenfeldbruck Airbase, all the remaining Israeli hostages, as well as five Palestinians, were killed. The next day the fiasco dominated the international press. ${ }^{5}$

Christoph Draeger's work Black September concentrates on what happened inside the apartment in Munich during that day on September 5, 1972. The core of the piece is a synchronized two-channel video installation which is shown in two separate rooms. The first room is a detailed reconstruction of one room in the Munich apartment according to photographs from the site of crime, including a vintage television set. It shows a bedroom in total devastation with bloody traces on blankets and floor. Many scattered clothes and personal items allude to the violent action that seems to have just recently lead to this chaos. The second room is an empty dark space and accommodates a video projection. Both videos - the one screened on the museum wall and the one that runs on the TV-set-run parallel. They basically show footage from Kevin MacDonald's official documentary film One day in September (1999) that deals with the terrorist attack during the Olympic Games in Munich in 1972.

In contrast to the video-footage that runs on the TV, some sequences on the screen projection are substituted by images that the artist created himself by re-enacting the events. Draeger reconstructed the bedroom of the Munich apartment within the exhibition space of Roebling Hall Gallery New York and re-enacted what he supposed had happened there. He recorded the re-enactement on video. Since then, the setting of this reenactment, that particular room in the Munich apartment, forms a consistent part of the screening environment in the museum 
installation of Black September. In a certain way, the artist has created a mis-en-abyme situation that again reflects on the precarious limits of the disaster zone; in other words, he provokes the emersion of the representation into the exhibition space.

The crucial part of the video are the scenes that the artist has created himself and that he intersperses with original documentary footage. The artist teases the imagination of the observer by supposing a scenery, which no one could have really seen from outside of Conolly-Straße 31 in the Olympic Village. As an effect of the montage, the re-enacted scenes and the documentary merge to a coherent unit in the viewer's mind (Ammann 2003: 24). Nevertheless, Christoph Draeger formally retains an amateur filming style to demonstrate the fictional character of the video.

Draeger's artistic process reveals on the one hand the viewer's indiscriminate consumption of images, on the other hand it shows how video images, once they are removed from their context, be it TV movies or news, become increasingly indistinguishable.

The art installation Black September questions the conditions of the mutual constitution of cultural memory and collective memory (Assmann 1994). As artefact, the artwork is part of cultural memory. It seeks to fill in the 'blind spots' of the collective memory that the official documentation, such as the footage from One Day in September, cannot supply.

Draeger's re-enactment of the missing link within the documentary is actually not based on testimony, but on forensic reconstruction of the event. Besides the documentary movie Draeger also uses photographs from newspaper reports in 1972 as inspiration for his artwork. His recreation of the hostagetaking fills a lacuna in the official collective memory, because there are no images of the action within the apartment before Draeger's artistic intervention.
This alludes to the question of the unspeakable and unimaginable within the reconstruction of traumatic events, (see Mitchell 2005) which is part of Draeger's artistic strategy. He-the artist-is the one who proposes a narrative that forms what before was unseen and unimaginable.

Draeger offers a possibility of how the history of this critical moment could be re-written and consequently, how the collective trauma could be accessed and processed. The art installation Black September, however, is limited to a museum audience. In a way, this artwork may be considered a prefiguration of what Steven Spielberg's movie Munich (2005) would make accessible to a larger public. ${ }^{6}$ In Spielberg's movie, the imagination of how the hostagetaking could have taken place is a key element of the traumatic plot. From this starting point, the collective memory of the Munich attack would be formed. In the course of the film, the imagination of terror is revealed through several flash-backs that show the brutal action inside the apartment and on Fürstenfeldbruck Airbase. The escalation of violence leads to the process of revenge in Spielberg's movie Munich.

The artist Christoph Draeger and the Hollywood director Steven Spielberg both offer a successful examination of collective trauma with their video and full length movie, respectively. In comparison to Spielberg's Hollywood movie, Draeger's video installation concentrates on the isolated sequence of the hostage-taking, that he includes within a haptic situation. Though Draeger obviously puts the traces of violence in the foreground, his artwork is more focussed on the topic of observation and self-reflection. The advantage of his artistic strategy is its double bind process of deconstructing the scenery. Through the correspondance between the two channels of the video installation and via split-screen inserts, the artist offers different perspectives 
on his video-documented re-enactment. In this mode of comparative observation the trauma that is represented through the images can be seen more clearly. The observers are standing within the site of the event, which means that they are forced to take the position within the scene, either the persective of the hostage-takers or that of the hostages whom they observe in the video. Through this kind of embedded reception, which Draeger creates in his installation, he puts the adience in proximity to the traces of the re-enactment in Black September that is only possible in a video art installation.

Art historian Inke Arns states that reenactment as artistic strategy unveils the uncanny in Freudian terms, i.e. "something that is actually known but has been repressed, from whence it returns" (Arns 2007: 63, see Hoffmann 2011). Today, re-enactment as an artistic strategy takes on a key-function in the processing of collective memory through cultural artefacts. Only the recreation and subsequent repetition of historic events can emphasize their significance as the decisive moment, which seeks explanation in order to be fully understood. Mostly, this significance is further stressed by cultural artefacts such as paintings, photographs or films that represent what is commonly understood as cultural memory. Especially works presented in the context of art exhibitions evoke a critical distance to the uncanny in history. Like Black September demonstrates, these images are part of a construction of memory which is based on media. Inke Arns asserts, "re-enactments are artistic interrogations of media images, which insist on the reality of the image but at the same time draw attention to how much the collective memory relies on media" (Arns 2007: ibd.). Because Draeger's installation is not a live re-enactment, but a representation of a terrorist act, it creates a critical distance through the remote presentation in the space of the museum. What Draeger presents as pieces of evidence for what really happened in Munich on September 5, 1972 is based on his imagination of spectacle, violence and murder. The artist himself gets involved in the play in his mimikry of a hostage-taker and terrorist.

When the viewer enters the space of the installation Black September by Christoph Draeger, the re-enactment has already taken place and is replayed in the video documentary. The visitors play the role of witnesses after the event. The only evidence left from the reenactment is a devastated room and a video of fictional representations of the event. The trauma is transferred into a distant closed circuit video-narrative.

One might say, in the situation of posthistoire, ${ }^{7}$ the assault on the Israeli hostages in Munich in 1972 is brought back to our collective memory by the artwork of Christoph Draeger and by the subsequent obsession of mass media with terrorism after the 9/11 attacks.

Sabine Himmelsbach explains Draeger's artwork in the context of contemporary terrorist strategies:

The world stands at shock over the current state of global terrorism, September 11th lingers in our minds, Intifada is unleashed in Palestine, and as such, the background setting for Black September informs our reading of both the actual event in history and of Draeger's representation. The distance in time allows for a fictional element, the myth has replaced the news. But thirty years later the same adversaries are still standing bitterly across from each other. Looking to address not just this condition but perhaps also its roots, Draeger goes on to ask, if the globalization of the image and the globalization of terrorism are not just coincidentally congruent; and asserts that violence and its simultaneous widespread illustration have always gone hand in hand. 


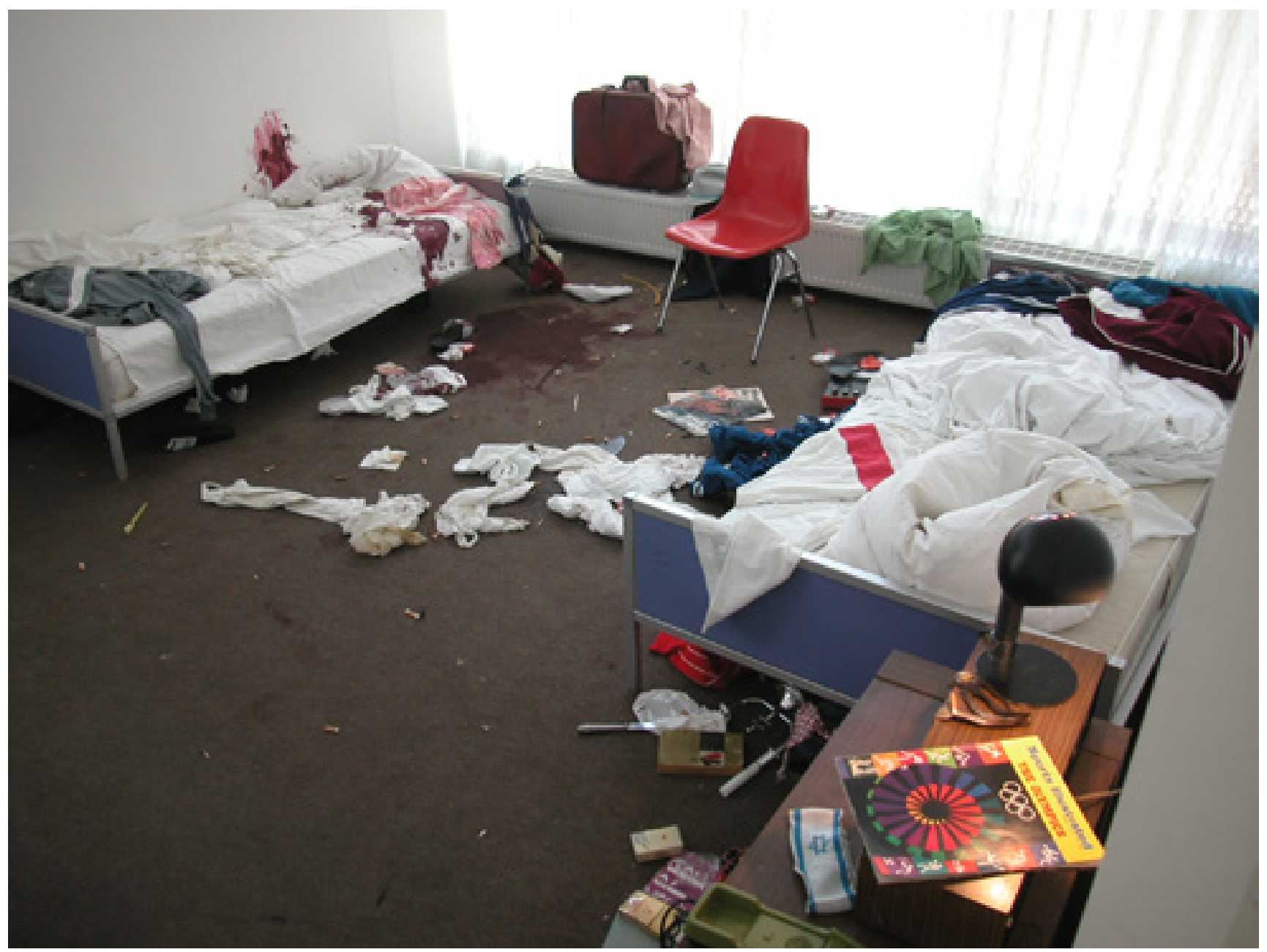

FIG. 5: KEVIN MCDONALD. ONE DAY IN SEPTEMBER. 1999.

Both terrorist attacks, in Munich 1972 and in New York 2001, mark the visual dominance of terrorism, which in case of September 11th and through the recurring images of the airplane-attacks and the collapse-explosion of the WTC proof the legacy of the "terror of attention" (Rötzer 2002), that would affect every spectator. Beyond the visuality, the effect of insecurity and fear is proliferated through the media reports about terrorism. This became obvious in the official comments that tried to re-create social cohesion in the US and worldwide after the terrorist attacks of 9/11. Every-day life should go on! This was the parole given by New York mayor Giuliani in his words: "Show you are not afraid. Go to restaurants. Go shopping." (Murdock 2001) In a similar way, Olympic Commitee member Avery Brundage commanded in 1972, "the Games must go on," there would be no interruption of the sports competition due to any terrorist intervention. The German art historian and theoretician Bazon Brock has coined the term "der verbotene Ernstfall" (forbidden emergency) as coping strategy for such situation. i.e. war and terror only are tolerated in fictional reality or as simulation (Brock 2002).

Both politics and art do not accept any interference through acts of terrorism, but instead try to encapsulate the terrorist trauma in cultural memory. On the one hand, through ritual events, monuments and fictional narrative the terror attacks are kept in rememberance. 
On the other hand, the abstract conjuration of the "war on terror" marks a desperate and helpless anti-strategy on how to cope with traumatic events. Quite forseeable, the trauma is only reinforced by this war.

In the first sequence of Draeger's video montage, the $\mathrm{ABC}$ newsspeaker Jim McKay is uttering the words "They are all gone." Except for three of the hostage-takers, all hostages and five Palestinians were killed at the Airbase Fürstenfeldbruck next to Munich in the night from September 5 to September 6, 1972. It was one of the most tragic moments in German history after the Second World War, and-again-Jews have been murdered on German soil. This is what caused the trauma in German national memory after the attack at the Olympic Games in 1972 and it lastet 40 years, until the official rememberance startet in 2012. Thus, politics finally offer the possibilty for public grief and solace. Newspapers like Der Spiegel reported on the circumstances of the historic event and how politicians today cope with the challenge of rememberance (Der Spiegel 2012).

In addition to this official way of coping with suppressed national memory and history, art provides representations that might be called "counter-history" oder "counter-discourse" in terms of Michel Foucault. The French philosopher explained how history and culture are confronted with counter-narratives that set oppositional or altering interpretations to official or popular definitions of historic events (Foucault 1990: 76). When Draeger frames his re-enactment with sequences from original documentary footage, he creates a reliable context, in which at first glance the restaged images could be taken for real. $\mathrm{He}$ thus blends a counter-narrative into collective memory. Within the installation spectators are nevertheless well aware that they are not part of the play. They appear in the centre of the scene - too late though - and can only observe and try to distinguish between fact and fiction. The stage is left in chaos, only the traces of reconstruction can be seen in the installation. After the event, terrorism has become a virtual phenomenon that can be analysed from a secure position - in both media and art. Terrorist violence has been turned into the "aesthetics of terror", as curator Manon Slone defines it. Images of terror tend to lose their signifie and get a new connotation when they become the icon of a radical-chic consumer culture (Slome 2009). This would create the myth of terrorism according to french philosopher Roland Barthes. In Mythologies, he calls the structure of myth a "second-order semiological system" when the original meaning of a sign is covered by new means.

In Christoph Draeger's installation Black September the myth of terrorism is translated into images that aesthetize the origin of the story. And yet, the re-enactment and its representation in the video installation seem like a coping strategy for lost signifiés. The artwork re-creates the event. It brings the terrorist action close to the spectator through emersive images, but technically obtains a critical distance through its mode of reflection upon the catastrophe (Baden 2007b). The installation Black September stimulates and simulates history and memory simultaneously. The artwork fills the void of a traumatic narrative. It tries to recapture the signs that have been unknown yet. What really happened inside the apartment?

\section{Interview with the artist Christoph Draeger:}

SB: Christoph, we are talking via skype. You are in your studio in Vienna. At the end of this conference day, we have just been watching your video Black September (2002), which is part of the complex installation on that topic that you have created. The video was made in 2002, it was produced in New York after 9/11. Since then, "war on terrorism" is dominating 


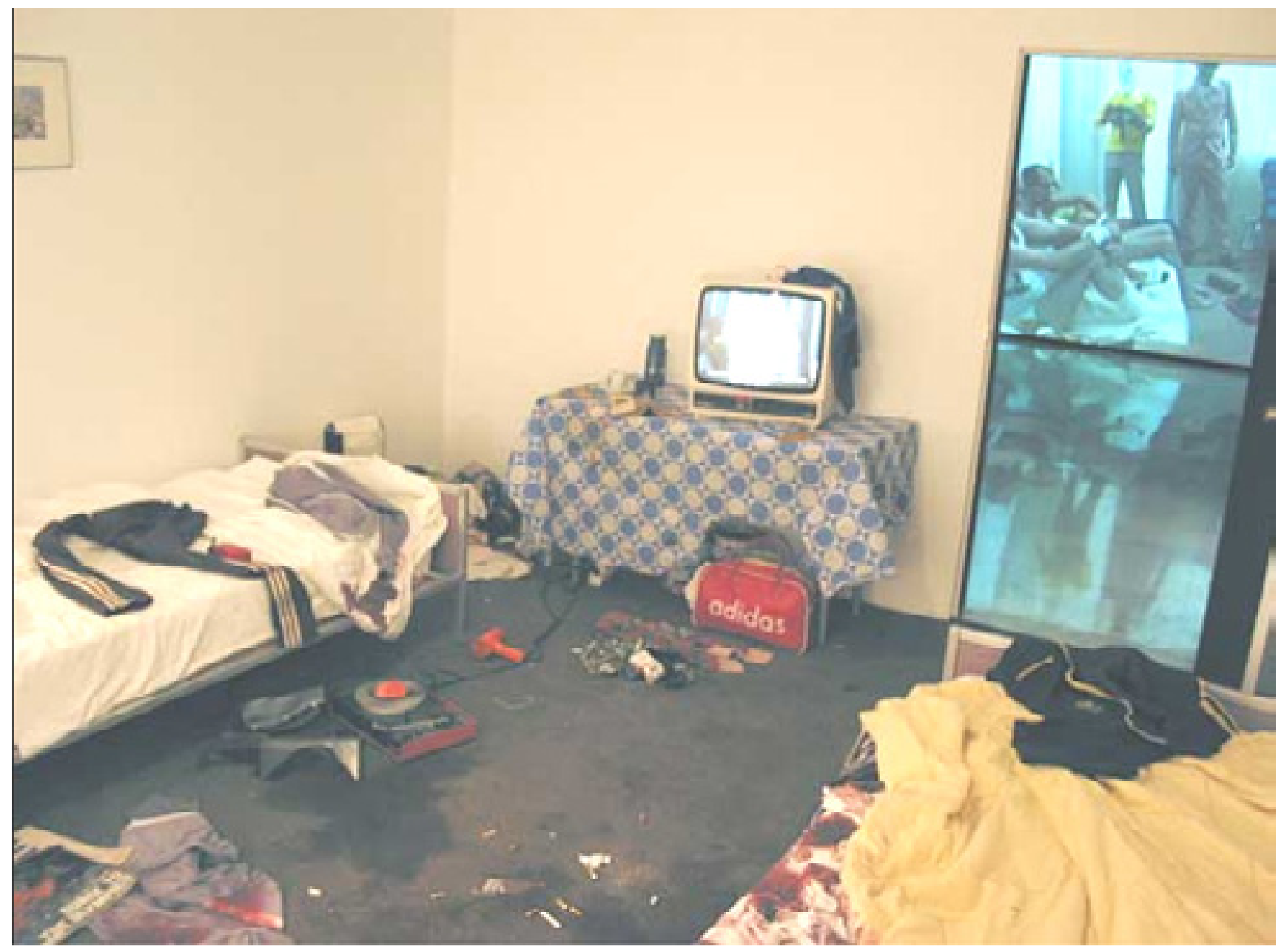

FIG. 6: MOVIE POSTER: KEVIN MACDONALD. ONE DAY IN SEPTEMBER. 1999.

the political agenda. In your video, you are dealing with Palestinian terrorists in 1972 in Germany, thirty years before the terrorist attacks on September 11, 2001. What was your motivation to produce the video and especially this installation?

CD: First of all, I produced this work for my upcoming exhibition at the Müller de Chiara gallery in Berlin in 2002. On September 11, in 2001, I was in New York and very close to the attacks. This had a strong impact on me, especially the unbelievable reaction of all the people and the media coverage on $9 / 11$. Television was occupied by replays of the attack, all the flags that hung everywhere and all the alleagance to "United We Stand" or similar pledges made me feel uncomfortable. This is why I produced a first video as reaction,
The Last News (2002), which clearly is a very sarcastic reckoning with media-reaction to catastrophes in general. It is a totally exaggerated satirical video which comments on a fictionalized terror attack-as innuendo to $9 / 11$. The catastrophe in the video happens within 13 minutes and rapidly leads to the end of the world.

During my research for The Last News I found the film One day in September, directed by Kevin MacDonald. It is a documentary about the terrorist attack in Munich in 1972 and was the Academy Award Winner in 2000 for Best Documentary Feature. It provoked my thought as I have been constantly dealing with catastrophes and terrorim in my artworks: I 


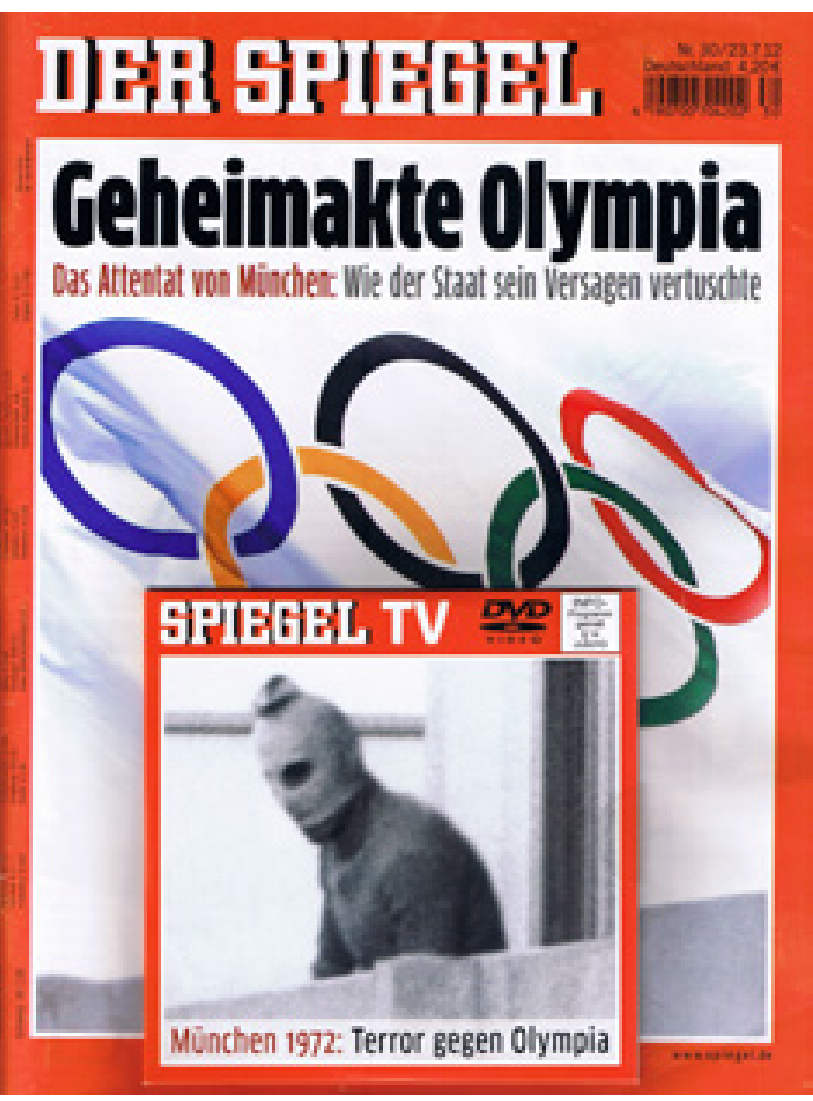

FIG. 7: COVER PAGE. DER SPIEGEL. GEHEIMAKTE OLYMPIA.

should do something in response to 9/11, but certainly nothing that is directly linked. There had been such an overload of reports and images in the media in the aftermath of September 11, 2001, I would have felt absurd to join in. Then I found this documentary movie and instantly knew: that is it, because it deals with a moment in history that in the meantime was almost forgotten. Even in Germany it had been blocked out in a way, probably because the assault had a bad impact on the image of Germany after the Olympic Games.

That's why I decided to appropriate the documentary One Day in September. Its producer Arthur Cohn is from Switzerland, he has Jewish ancestors. His movie obviously treats the Palestinians as evil. But through many reports we know that there are reasons for Palestinian terrorism that are likely concealed. However, I only wanted to put the events in a timeline, just a they happened, without stereotyping the Israeli as victims, the "nice guys," while letting the Palestinians play the role of "evil." I really attempted to objectivize the whole thing-knowing this sounds like a strange intention. I concentrated on the footage of this documentary. Because the director used music to reinforce the atmosphere, I could not separate the original soundtrack from the commentary of the anchorman. Thus I integrated the music into my video, too. Now, it automatically has the same dramatic effect.

After this, I produced the video installation Black September in the summer of 2002. I remember it was terribly hot when we did the shooting for the video. I built the set in the gallery space of Roebling Hall and recruited actors from my friends. The fact that I played the terrorist, by the way, was due to an emergency. I did not plan to play Issa ${ }^{8}$ myself, but the main actor, who also participated in the video The Last News (2001), did not want to come that day, he simply did not appear, that is why someone had to play Issa. So I did it. Later I showed the video in Germany in September 2002. There were some reactions. I got a few reviews, in the Berlin Zitty-Magazine and in some other newspaper in Berlin, but nothing else happened, I have to admit.

SB: What was in general the status quo of remembering the 1972 attack on the Olympic Games in Munich in 2002, just one year after the terrorist attacks in New York?

CD: In comparison to 2012, when we commemorated the 40th anniversary of the attack, there was almost nothing recognizable in 2002. There was no issue of Der Spiegel with that theme on its title, the newspapers only published a few articles that were commemorating the events 30 years ago. All this commemoration-machine, that has just begun to run-probably also because of the current Olympic Games in London in August 


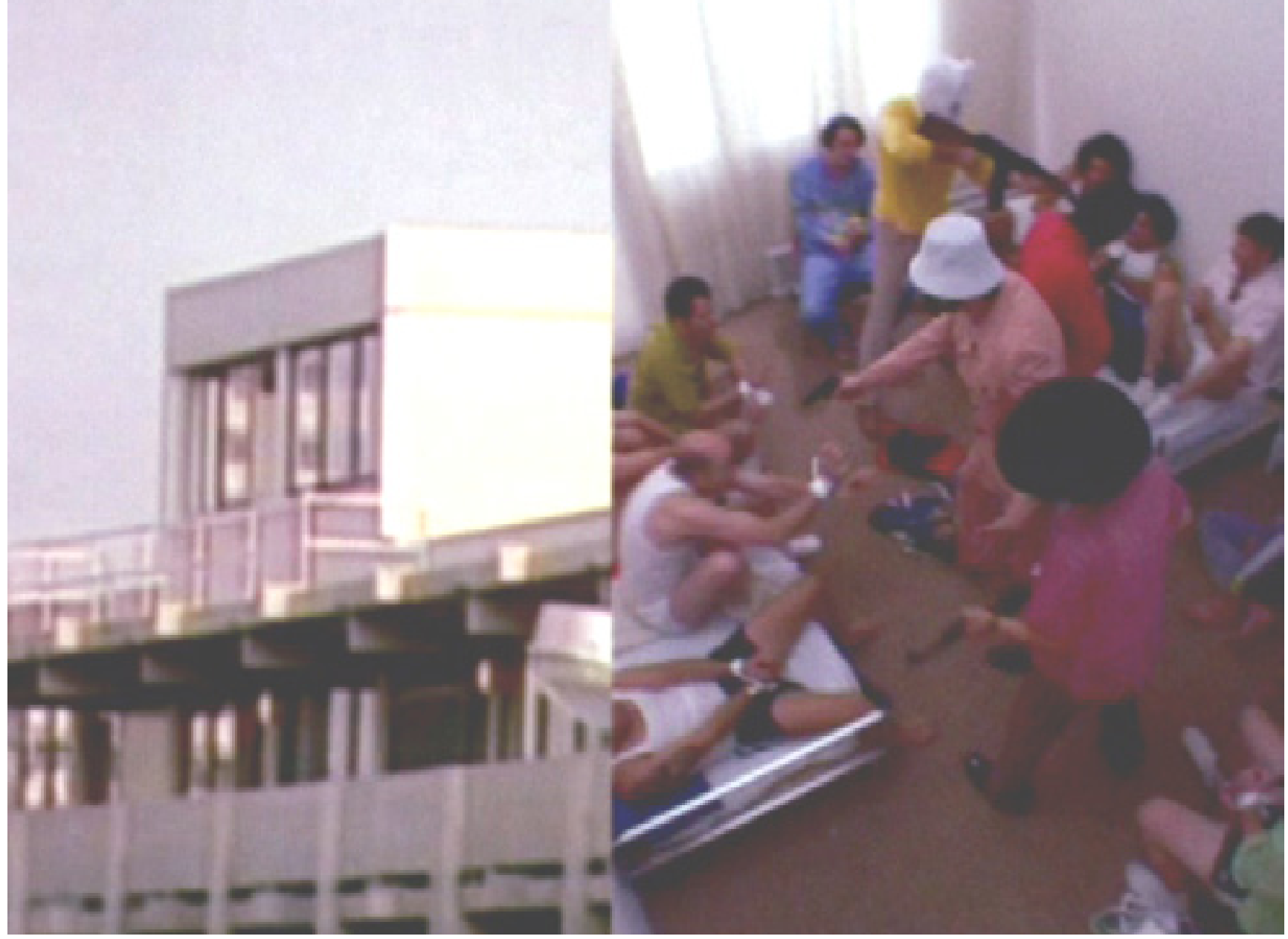

FIG. 8 AND 9: CHRISTOPH DRAEGER. BLACK SEPTEMBER. 2002.

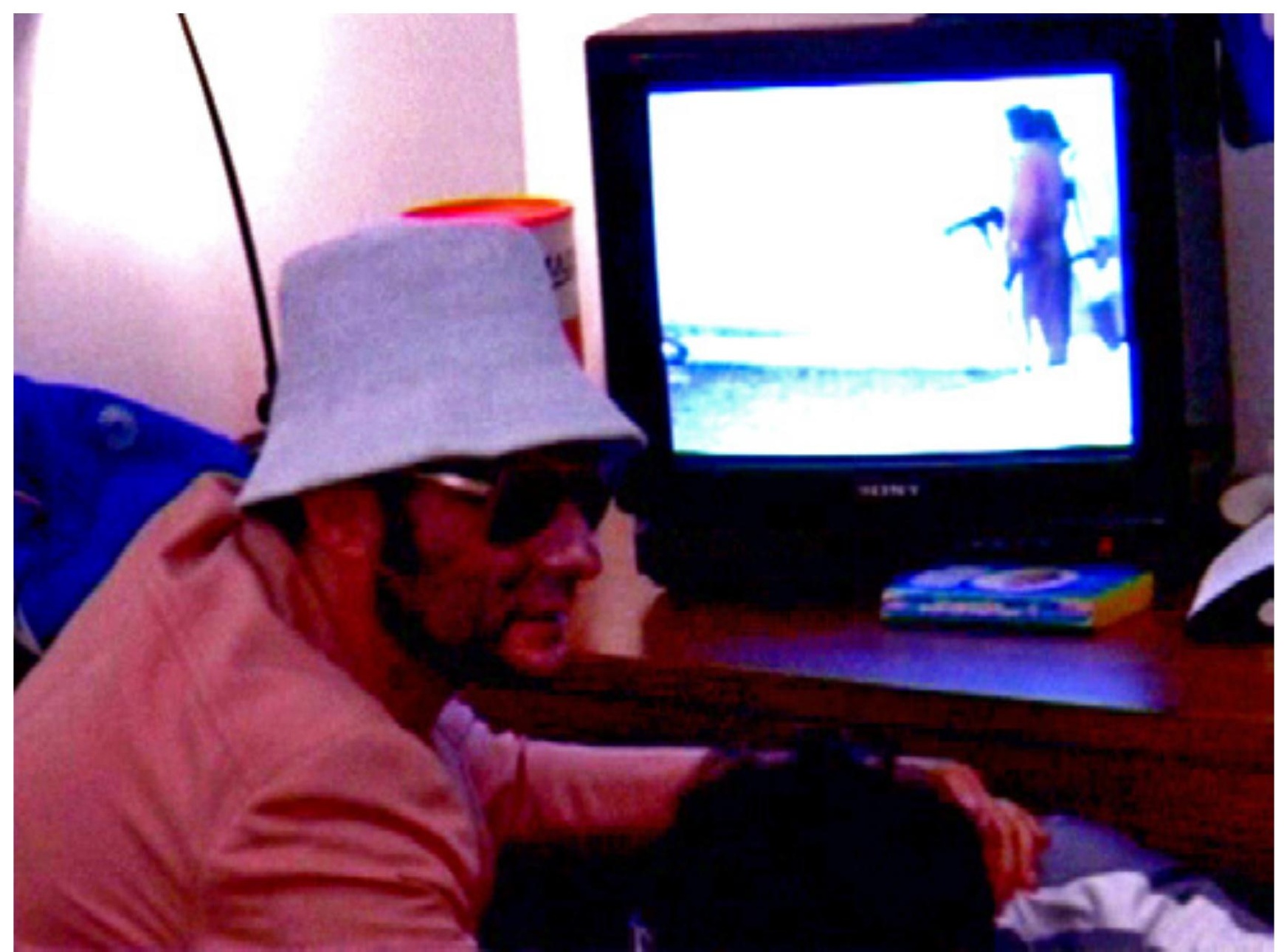


2012- did not exist just ten years ago. My installation was shown the second time at Roebling Hall Gallery in New York, but for me it was significant that it was produced especially for a German context and also was shown there first. Hence, my attempt to show the exhibition at the same time as the 30th anniversary in September 2002 worked out and hit a nerve.

SB: From the perspective of art history, we are interested in the production and perception of images. How does the artist work with images, where does he take pictures from, and how does-in comparison-television deal with visual testimony and authenticity? Your installation consists of two rooms that are connected, as we can see on the floor-plan. The situation within the apartment is reconstructed according to the original setting in Munich, Connolly-Straße 31, right in the Olympic Village. All inventory has been composed in the contemporary style of early 1970s design, even the bags, the TV, the clothes. There are churn up beds, litter, traces of blood among all kind of scattered accessoirs on the floor. Only the corpse is missing, which is shown in the video and on one of your production stills. On the small TV you can see original footage from the news coverage. In the next room, the video projection shows re-enacted sequences. Obviously, it is important for you to show the visitor the opportunity to look out of the room through the door of the balcony, though in the exhibition there is no real exit, just some light behind a curtain. You have two situations that can be switched, depending on if you first enter the video projection or the apartment. On the one hand, there is the video that shows the restaged events, and on the other hand, the observer enters this set of destruction-and later gets to know what happened when he is watching the video. What motiviated you to choose this presentation structure?
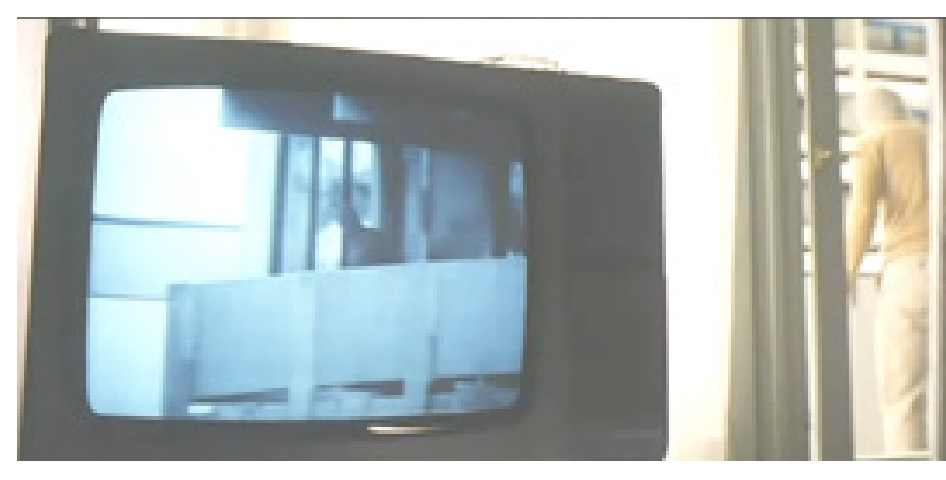

FIG. 10: STEVEN SPIELBERG. MUNICH. 2005.

CD: The main idea-and probably the most important one-was to imagine, that both terrorists and hostages could attend the live-broadcasting of their own drama. The concept of my installation is inspired by the imagination to enter the room just like in that moment, when Ankie Spitzer-the wife of one of the murdered Israeli-came in, right after the drama happened. The corpse is missing, only the destruction is visible. And just like a media 'afterglow' the TV is still showing the same news that also her husband, respectively all hostages and terrorists have been watching, and which, of course, influenced all the subsequent events. It was the news that informed the terrorists about how the German police tried to take over the situation by assault-going over the rooftops during "Operation Sunshine." That is why the assault was soon cancelled. For me, this live-feedback was extremely important to conceptualize my artwork.

In fact, the concept of the installation is based on found-footage that I show on the small TV in the destroyed room. You have to know that the documentary timeline is running at the same scale as my reenactment-video in the dark room. The audio-track is the same in both videos, also the framing news run parallel, but on TV you cannot see my re-enactment, you just see the documentary footage.

SB: On the flat rooftop on the opposite side of Connolly Straße 31, the team of the GermanDemocratic Republic-TV and many other 
teams were live-broadcasting and filming all day. I guess, the crucial point in your installation is the situation of the observer who actually gets the impression of being observed, too. This observation is an exciting moment because in your artwork it does not only refer to the historical moment in reallife politics that is documented in the newscoverage, but also to art history. It is about the self-observation of the observer. This idea of constructing a "closed-circuit" installation was a new artistic strategy in 1972, when spectators become their own observers in the video within the exhibition. US artist Dan Graham invented this construction for his Installation Time Delay Room (1974). This way, the situation of the observer within the exhibition is emphasized and the spectator focuses on his own role. That feedbackconstruction within your installation is the essential connection. Two screenshots demonstrate how you created the montage of the images. The Splitscreen shows the perspective of the news-teams from outside on the left next to an interior scene depicting the re-enactment on the right.

CD: Yes, one might say the point is that this situation in Munich seems as if it was actually created for the terrorists. Of course they took advantage of this global stage, as it has often been confirmed. Hence, concerning the closedcircuit feedback, one of the terrorists could have literally confirmed his media appearance by just stepping on the balcony and turning around to see himself on television. I emphasize this situation by having my artist colleague Rainer Ganahl, dressed as terrorist, stepping out through the balcony-door. Then I made a cut at the same moment, switch to the originial footage, to show the real terrorist who was filmed on the balcony in 1972. I tried to bring a logical coherence between the images of the footage and my re-enactment.

SB: I depicted a scene for comparison which demonstrates this cutting point. It is not taken from your video, but from Steven Spielberg's

IMAGINATIONS •ISSUE 5 - 2, 2014 • 134 movie Munich (2005) who shot the same scene, of course. Spielberg put the television on the other side of the room, right in front of the curtain that obscures the window. Thus you can see at one glance how the terrorist is filmed from outside at the same time when he is stepping on the balcony. Spielberg shows this observation explicitly, the terrorist's persistent appearance on the balcony to check what's going on outside. The director reduces complexity for the viewer when he pretends to demonstrate the truth.

CD: I have to say, Spielberg made his film after I had done my work. And probably, even after he had seen my video. Hence he said to himself: "I will certainly avoid obvious mistakes in scenography." (laughing)

SB: Spielberg shows explicit violence in his film, like in the brutal scene when Joseph Romano is shot dead. As dramatic strategy he uses slow motion and puts the torn up bodies into the focus of the camera. This is, of course, a big difference to your production, you had less budget and non-professional actors. In your video, the violent aspect is played very elegantly, because of the concealed act of killing. Right at the moment of the execution, when one of the hostages is shot dead, you cut, the image switches to the shooting starter's gun at an Olympic running competition on TV. That is very clever-and no coincidence, I guess?

CD: Of course not. I tried to point out the fact that the Olympic Games went on despite of this murder. Therefore I inserted the starting shot as important symbol. In my video I wanted to combine two aspects. The TV in the apartment was constantly running, hence the hostages and the hostage-takers did not only follow their own drama on television, but probably also saw the live-broadcasting of the Olympic Games, as long as they were going on. That is why I thought it would be elegant to edit the original murder with the starting shot. 


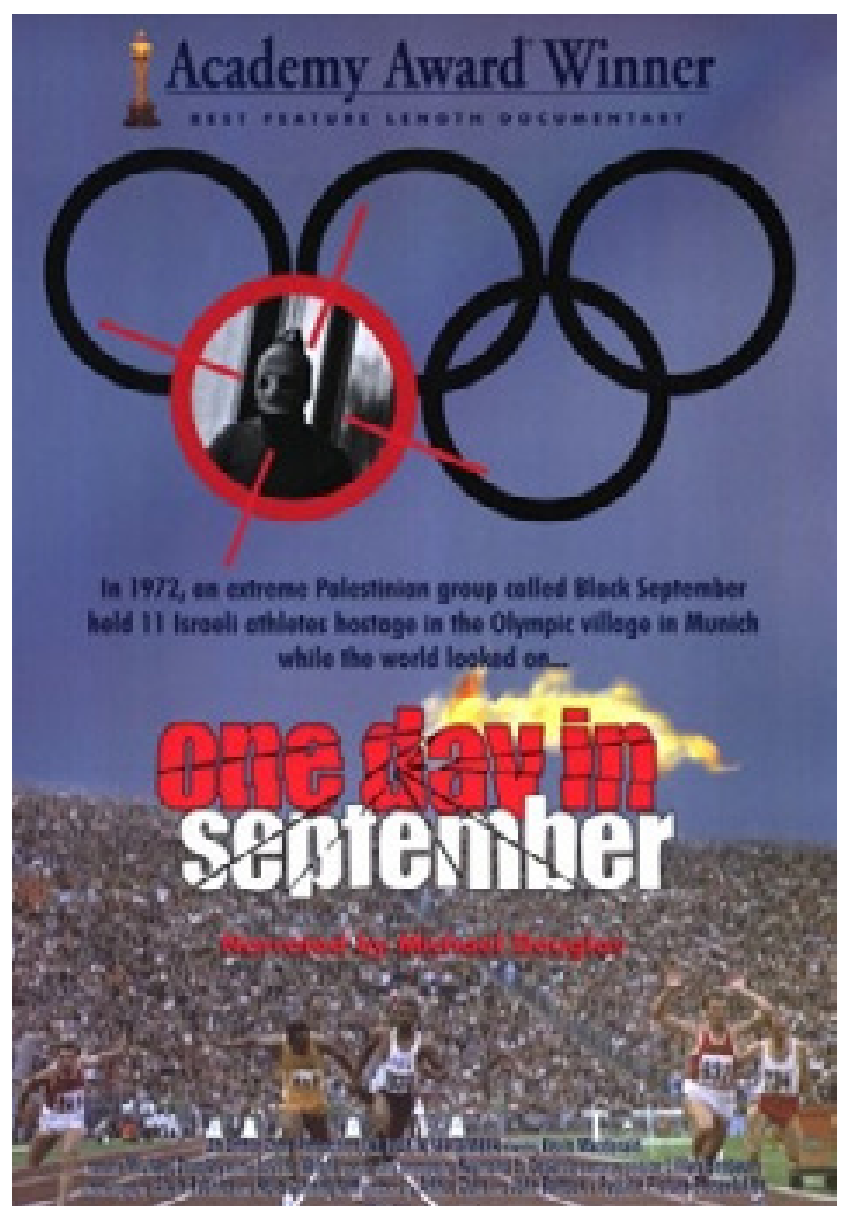

Question from the audience (Thomas Nachreiner):

I was wondering, if the crossfade from starting shot to murder could not be understood vice versa, concerning the trigger for memory-culture. Hasn't the attack been the starting point of a media event that we are commemorating for many years and over generations? Otherwise the Olympic Games in 1972 would have been one among many? Is the artwork not pointing to that ambivalence?

$\mathrm{CD}$ : The symbolism of the starting shot is rather menacing and does not really relate to the idea of "bright games." "And since 1972, the Olympic Games are not bright any more, but protected by a shield of thousands of policeofficers. There is a similarity to civil aviation which also was a bright hobby for rich and wealthy people. However, since 'skyjacking' ${ }^{10}$ occurred, travelling has become distressful by all this control apparatus at airports which is of course absolutely necessary. I am even convinced that contemporary terrorists would exploit the current Olympic Games in London 2012, if they only could. But they cannot anymore because there is no access available like before in Munich. That is why I would agree, the starting shot has symbolic significance.

SB: Christoph, let us speak about your own role as an actor in the video. How do you stage a terrorist? You tried to restage the actors and their outfit according to documentary footage. You present several stereotypes: the guy with a machine gun and his mask gives a clichee. Next to him there is Issa. With black shoepolish make-up on his face and a white hat, he looks like a comedian. There is a third person with Ray Ban sunglasses and a cowboyhat, similar to a Maverick, that American Western-hero. He is smoking cigarettes. He also reminds me of the Marlboro-Man. What is the basis of such aesthetic? Do these outfits refer to original characters, that you saw in newspapers reports?

CD: That is delicate, because now we speak about having fun in my production. In a certain way, my re-enactement is sort of a game, but it restages extremely sad events. Almost like kids that play cops and robbers. In several scenes you become aware of the ironic alienation that should be a signal not to take the video too serious. I am aware, this does not really fit with the drama and the effect of the events. In many of my works I do not only depict terror, but catastrophes in general. I dare to exploit my artistic liberty, my jester's licence, which is not available to Spielberg in his commercial cinema, for example. He would not be allowed to show ironic exaggeration-I guess-without being punished later, whereas for me, because I work in a smaller, secure space-in art-I take 
the liberty of doing so. This way, I can change common layers of perception. If tragedy is not treated really seriously anymore, then you can profit from ironic alienation. This allows some funny effects, like Rainer Ganahl has to smoke in my video-for the very first and last time in his life. He originally is a militant nonsmoker. You can see he smokes really badly.

\section{Question from the audience by Eva Herschinger:}

Doesn't irony perhaps bring some relief, just like we know from theater? On the one hand, you stiffle your laughter, but on the other hand you have the impression that everything is not that serious. This creates a feeling of relief which simultaneously turns into disappointment. Perhaps, the irony that you use as an artist does not always seem to be suitable.

CD: There is still another element-the plot is very dramatic. The drama happens within these 14 minutes. Finally there is a void: death. That is all known, there is no redemption in any sense. You can insert a certain level of alienation into fiction, but in the end, any laughter stiffles because there is no escape from fate in this story.

SB: We already talked about the two forms of presentation. How did you change the installation?

$\mathrm{CD}$ : There is an endless variety of presentation modes, because every time when I set up the installation, it seems like a new work for me, due to the fact that I am constantly arranging things a little differently. Maybe this relates to shifting memories. Though I have the same elements, I do not use all of them every time. SB: But you need a kind of a suitcase with requisites, to keep all props like bags, TV, shoes, clothes available...
CD: Those parts wander, of course. They are in stock and I sent them to the exhibitions. Sometimes the dimensions of the two rooms are different, according to the museum space, and it happens that people from the staff get measures wrong or make any other mistake, then I have to adjust the installation. In general, as I said, there is little difference when a visitor has seen the work in Antwerpen in 2006 or now again in Toulouse in 2012. He will say it is the same work. There are no dramatic changes, only subtle variations. There is also the possibilty to show only the video as projection or on a single monitor, but that is uncommon. The Centre Pompidou showed it that way. Normally, I insist on the presentation of the whole installation.

SB: If we take a look back, we are now 40 years after Munich, eleven years after 9/11. How do you see your work and its reflection of media and cultural memory in relation to 1972?

CD: It is difficult to judge, because I have not really been close to the events in 1972 . I was a child and I can hardly remember, but all I know is of course what everyone knows from movies, the news coverage, books etc. For me, it is challenging to think about the adverb "back then" and what it means, or what impact the global TV-broadcasting had on us. For example, I can better remember the first man on the moon than 1972 in Munich, just because perhaps my parents allowed my to watch the moon landing. They spared me the events in Munich. At that time, when the Olympic Games took place, I was seven years old.

But the way in whih terrorists used the world as stage was, looking at the example of Munich, accomplished at a high level of sophistication. It was the first time when Olympic Games have been broadcasted live around the world and the terrorists instantly capitalized on 
their chance to get attention. After Munich 1972, the terrorist attacks on 9/11 were much bigger in scope, also because today we have more media coverage, we are far more linked. Everyone saw it on a different screen. In 1972, there were only a few programs available, and radio. Today you could see an event like 9/11 everywhere, and it has constantly been replayed. I think the conceptual difference was much less than we assume, between 1972 and 2001.

Comment from the audience (Simone Egger): Everytime when I am walking through Connolly-Straße, I feel like a movie is repeatingly played in my head. I always try to reconstruct the events in my mind and reflect about what might have happened inside the apartment. I automatically insert the images from the media into my memory. That is why I think your installation exemplifies this reflection much more precisely and more real in comparison to any slick documentary.

CD: It is certainly a method of identifying with the events when I restage things like that. There are societies that are interested in re-enacting historical events, like the battle of Gettysburg. These societes dress in historical costumes and meet annually at the historical site to re-enact the event. There is this famous artwork by the British Artist Jeremy Deller, called The Battle of Orgreave (2001). ${ }^{11}$ For this re-enactment he asked English mineworkers, policeman and volunteers to re-enact the battle they fought with the British police 16 years later. He even put real policemen on the set.

SB: But Jeremy Deller also allowed some actors to switch roles, the policemen played miners and the miners were policemen-just to alienate the conventional way of role-play (Farquharson 2001). The artist cracked the code of representation. He would not do the same as the re-enactment society. That is similar to your work when you play the terrorist in your re-enactment.
CD: I believe re-enactment has much explosive potential because it is not left to Hollywood only. We do this already as children. We try to cope with experience by restaging and simultaneously reflecting what we look like when we play. That is important for many re-enactments, not only mine. I did many re-enactments in the nineties, but my work about Munich was propably the most discussed. Before I did reenactments of violent Hollywood- movies. But anyone could do this. When you look at such a work and you see how the artist has created it by using only few things, a very cheap and rapid shot, like a sketch, like something everyone could do with a video camera, then you know spontaneity is part of the game. This spontaneity allows variations of real facts. Perhaps, improvisation also helps to develop a closer relation to the event and then you can handle it in one way or another. That is what my strategy is. This is the main reason why I do my work at all, I do not want to leave the stage only to Mister Spielberg.

\section{Simone Egger:}

Have you shown your video in Munich or why did it not work to show it here?

CD: No, I have not yet. The Black September video has never been shown in Munich. But I showed it in very close distance, last year in 2011 at the Museum der Moderne in Salzburg. Nevertheless, 40 years after the Olympic Games attack it would have been perfect to show it here in Munich.

SB: I know, our host today here in Munich, the Bundeswehr (German Army) has a military archive. But it is only for real weapons. They don't collect artworks yet.

CD: A propos Army. In my video, the footage quotes a phrase by the american news reporter after the disaster has been made public on September 6, 1972: “The German Army, because of very complicated laws, was not 
allowed to participate." Thus, the Bundeswehr cannot be accused for the failure of the police at Fürstenfeldbruck Airport, when so many people died at the end.

SB: How do you think the space of the museum and artwork in general can function as an agent for peace and a civil society? Like an institution, similar to a democratic parliament, whose discourse level creates an opportunity to discuss and solve conflicts, but not outside common political processes?

CD: Naturally, we have to stay realistic and admit, that art has no regular impact on society. There are few exceptions, like the Chinese artist Ai Wei Wei who has already been punished because he articulated subtle protest against the Chinese government. When I do such an artwork, I want to offer a dispositive that has not yet had a format of discussion. In addition, I hope someone might see it. But how many people would see the whole installation, if not right at a documenta-exhibition in Kassel/Germany? And even if it was shown at documenta, on such a big event, everyone is only consuming art just as a "must have"! Within one or a few days you rush through the exhibition without remembering much afterwards. I am realistic, unfortunately, not very optimistic. Art belongs to leisure today, to a general cultural attraction that society creates for itself-I am part of that. And if I would show even more blood or brutality in my video, people would be callous, look into the installation and ask, "oh, what was that?", then they go to see the next artwork. I am not very optimistic about the efficiency of art as a trigger for social change, but I believe, it has some effects, though, just like your terrorism research-network. ${ }^{12}$

SB: Thank you. We will stick to that.

(Endnotes)

1. The term "counter image" was prominently deployed by the recent exhibition Bild-Gegen-Bild/Image Counter Image at Haus der Kunst München in 2012 (Dander and Lorz 2012). For the origin of the term, see Meyer 2009.

2. http://www.christophdraeger.com/ categories/data/categories/04_Videos/ LastNews/03

3. After the terrorist attacks of $9 / 11$ Slavoj Žižek's theory is often referred to as explanation of the shock that was proliferated through the media (Zizek 2002). Zizek himself quotes this metaphor from the movie The Matrix, directed by the Wachowski Brothers in 1999. Whereas the Wachowskis refer to French philosopher Jean Baudrillard who already coined the term in 1978 in his book "Simulacres et Simulation“ (Baudrillard 1994: 3). „The desert of the real" signifies what Baudrillard describes as „hyperreality“, according to the surrealist writings of Jorge-Louis Borges, meaning that reality has been replaced by the indifference of the "precession of simulacra“. In 2001, the notion of simulation has often been discussed by media theoretics in the aftermath of September 11th.

4. The „Black September“-group was founded after the PLO was dispersed from Jordan. It was part of the el-Fatah organisation in Lebanon and the al-Saikah organisation in Syria (See Dietl et. al. 2006: 43-45; Forster/Knieper 2008).

5. The three Palestinian hostage-takers who had been imprisoned in Germany, were released to Lybia in November 1972. Many documents and historical information about the event are contained on the unofficial website: "Die Spiele der XX. Olympiade München 1972.” Web. 5. March 2013. http:// olympia72.de/attentat1.html, See Reeve 2000; Forster/Knieper 2008. 
6. Munich, directed by Steven Spielberg, USA 2005. Screenplay by Tony Kushner and Eric Roth, based on the novel Vengeance: The True Story of an Israeli Counter-Terrorist Team by George Jonas, first published in 1984.

7. Daniel Binswanger refers the the term 'posthistoire' coined by Alexandre Kojève when he speaks about Draegers works that are created after the catastrophe, which means they are delayed. „Draeger's ease is a symptom of inescapable tardiness that one attempts to designate as posthistoire." (Binswanger 1999: 55)

8. Issa was the name of the leader of the Black September group who negociated with the state deputies and knew to speak the German language, too; he is the one of the Palestinians with the white hat and black make up face, he also has been photographed the most.

9. In Germany, the Olympic Games in Munich in 1972 were announced as "Heitere Spiele", because they should bring the new "bright" Germany to the attention of the world audience. This should mark the difference to the Olympic Games in Berlin in 1936 that were dominated by NaziPropaganda.

10. The term ,skyjacking' is derived from its origin , hijacking', but especially refers to airplane-hijacking. Most prominent female skyjacker was Palestinian Leila Khaled, photographed by Eddie Adams, See: "A Day With The Arab's No. 1 Lady Skyjacker." The Victoria Advocat 29 Nov. 1970: 62. Print.

11. On June 18th, 1984, the conflict between the British National Union of Mineworkers and the British government escalated in a violent clash near the coking plant of Orgreave in South Yorkshire. Margaret Thatcher, who was determined to break the power of trade unions, sent out police units to disperse the protesting miners. The British artist Jeremy Deller did research on that event and revived history in cooperation with former participants of the „battle“, supported by so-called „re-enactment“ groups, miners and policeman. The reenactment was documented by Mike Figgis for Channel 4 television, combining scenes from the restaged event on June 17th, 2001, with documentary photographs of the clash of 1984 (Wagner 2007).

12. Since 2007 the German TerrorismResearch-Network NTF e.V. (NetzwerkTerrorismusforschung) is offering an academic exchange platform for interdisciplinary scholars who do research on different topics in relation to terrorism and political violence. www.netzwerkterrorismusforschung.org

\section{Works Cited}

Ammann, Katharina. „Too Much of a Bad Thing. Terrorism and Other Catastrophes from a Safe Distance." Christoph Draeger. Memories of Terror from a Safe Distance. Ed. Kunstmuseum Solothurn, Frankfurt am Main: Revolver, 2003. 20-31. Print.

Arns, Inke. "History Will Repeat Itself." History Will Repeat Itself. Strategien des Reenactement in der zeitgenössischen (Medien-) Kunst und Performancel Strategies of Re-enactment in Contemporary (Media) Art and Performance, Eds. Inke Arns, Gabriele Horn, and Hartware MedienKunstVerein Dortmund and KW Institute for Contemporary Art Berlin, Frankfurt am Main: Revolver, 2007. 37-63, 63.

Assmann, Aleida, and Jan Assmann. "Das Gestern im Heute. Medien und soziales Gedächtnis.” Die Wirklichkeit der Medien. Eine Einführung in die 
Kommunikationswissenschaft. Eds. Merten, Klaus, Siegfried J. Schmidt, and Siegfried Weischenberg. Opladen: Westdeutscher Verlag 1994. 114-140. Print.

Baden, Sebastian. "Terrorkunst. Die ästhetische Distanz zur Katastrophe.“ Terminator - The Potential of the End. Destruction and Coping-strategies as Creative Processes. Ed. Sebastian Baden. Bern, Karlsruhe: Hochschule der Künste Bern, Staatliche Akademie der Bildenden Künste Karlsruhe, 2007a. 100-110. Print.

Baden, Sebastian. "Modellkatastrophen und das Puzzle der Rezeption. Zur Zerstörung im Werk von Christoph Draeger. “ Die Zerstörte Stadt. Repräsentationen urbaner Räume von Troja bis Sim City. Eds. Böhn, Andreas and Christine Mielke. Bielefeld: transcript, 2007b. 339-365. Print.

Barthes, Roland. Mythologies, London: Paladin, 1972. Print.

Baudrillard, Jean. Die Agonie des Realen. Berlin: Merve, 1978. Print.

Baudrillard, Jean. Simulacra and Simulation. Ann Arbor: University of Michigan Press, 1994. Print.

Binswanger, Daniel. "On the Localization of Apocalypse.” Christoph Draeger. Disaster

Zone. Ed. Zeppelin Museum Friedrichshafen, Orchard Gallery Derry, Kulturhaus Rosengarten Grüsch, Galerie Urs Meile Luzern, Friedrichshafen: Gessler 1999. 5461. Print.

Brock, Bazon. „Kunst und Krieg - der verbotene Ernstfall.“ Kunst + Krieg. Eds. Brock, Bazon und Gerlinde Koschik. München: Fink, 2002: 275-284. Print.
Der Spiegel; ler/dpa/dapd. “OlympiaAttentat 1972: Gedenkfeier für die Opfer von München." Spiegel-Online, 5 Sep. 2012. Web 18 Aug. 2013; http://www.spiegel. de/politik/deutschland/olympia-attentat1972-gedenkfeier-fuer-die-opfer-vonmuenchen-a-854183.html

Dietl, Wilhelm; Kai Hirschmann, and Rolf Tophoven, Eds. Das Terrorismus Lexikon. Täter, Opfer, Hintergründe. Frankfurt am Main: Eichborn, 2006. 43-45. Print.

Dander, Patrizia and Julienne Lorz, eds. BildGegen-Bild/Image Counter Image. Haus der Kunst München 10. Juni - 16. September 2012, Köln: Verlag der Buchhandlung Walther König, 2012. Print.

Hoffmann, Felix and C/O Berlin, eds. Unheimlich vertraut/ The Uncanny Familiar. Bilder vom Terror/ Images of Terror. Köln: Verlag der Buchhandlung Walther König, 2011. Print.

Farquharson, Alex. "Jeremy Deller. The Battle of Orgreave." Frieze no. 61/ September (2001). Web 03 March 2013. URL: http:// www.frieze.com/issue/review/jeremy_deller/ (03.03.2012)

Forster, Klaus, and Thomas Knieper. „Das Blutbad von München. Terrorismus im Fernseh-Zeitalter." Das Jahrhundert der Bilder. 1949 bis heute. Bd.2, Gerhard Paul, ed. Göttingen: Vandenhoeck\&Ruprecht, 2008: 436-441. Print.

Foucault, Michel. Die Ordnung der Dinge. Eine Archäologie der Humanwissenschaften. Frankfurt am Main: Suhrkamp 1990. Print. [The Order of Things. An Archaeology of Human Siences, New York: Pantheon Books 1970.] 
Himmelsbach, Sabine. Christoph Draeger. Black September. Web 13 March 2013. http:// www.christophdraeger.com/categories/data/ categories/03_Installations/01_Black $\% 20$ September/02

Meyer, Petra Maria, ed. Gegenbilder. $\mathrm{Zu}$ abweichenden Strategien der Kriegsdarstellung. München: Fink, 2009. Print.

Mitchell, W. J. Thomas. „The Unspeakable and the Unimaginable. Word and Image in a Time of Terror. " English Literary History, 72. 2, Summer (2005): 291-308, [Rpt. in Mitchell, W.J.T. Cloning Terror. The War of Images, 9/11 to Present. Chicago University Press 2011.] Print.

Murdock, Deroy. “Giuliani’s Finest Hour. The mayor's emergence." National Review Online, September 14, 2001. Web 16 Aug. 2013. http://www.nationalreview.com/ articles/205017/giulianis-finest-hour/deroymurdock

Reeve, Simon. One Day in September. The Full Story of the 1972 Munich Olympics Massacre and the Israeli Revenge Operation „Wrath of God". New York/London: Arcade Publishing 2000. Print.

Rötzer, Florian. "Das terroristische Wettrüsten. Anmerkungen zur Ästhetik des Aufmerksamkeitsterrors.“ MedienTerrorKrieg. Zum Kriegsparadigma des 21. Jahrhunderts. Eds. Goedart Palm and Florian Rötzer, Hannover: Heise, 2002. 86104. Print.

Slome, Manon. "The Aesthetics of Terror." The Aesthetics of Terror. Eds. Joshua Simon and Manon Slome, Milano: ChARTa, 2009.8-29. part 1, Web 13.03.2013. http://www.artlies.org/article. php? id $=1760 \&$ issue $=62 \& s=$
Wagner, Renate. "The Battle of Orgreave." History Will Repeat Itself. Strategien des Reenactement in der zeitgenössischen (Medien-) Kunst und Performancel Strategies of Re-enactment in Contemporary (Media) Art and Performance, Eds. Inke Arns, Gabriele Horn, and Hartware MedienKunstVerein Dortmund and KW Institute for Contemporary Art Berlin, Frankfurt am Main: Revolver, 2007. 86-89. Print.

Žižek, Slavoj. Welcome to the Desert of the Real. London/New York: Verso, 2002. Print.

\section{Image Notes}

Figure 1: Christoph Draeger, Black September. 2002. Synchronized two-channel video installation, DVD 14:30 min. loop, destroyed hotel room, dimensions variable, Installation view, Alcala 31 Contemporary Art Center, Madrid 2003. Courtesy the artist.

Figure 2: Christoph Draeger. The Last News. 2002, Video, MiniDV to DVD, 13 min, Ed. of 5, videostill, Christoph Draeger and Reynold Reynolds, Digital animation by Gary Breslin/ PanOptic, Starring Guy Richard Smith. Courtesy the artist. Web. 13.03.2013. http:// www.christophdraeger.com/categories/data/ categories/04_Videos/LastNews/06

Figure 3: Christoph Draeger, Black September. 2002. Synchronized two-channel video installation, DVD 14:30 min. loop, Videostill. Courtesy the artist.

Figure 4: Christoph Draeger, Black September. 2002. Synchronized two-channel video installation, DVD 14:30 min. loop, Installation view, Galerie Müller Chiara Berlin 2002. Courtesy the artist.

Figure 5: Kevin McDonald. One day in September. 1999. Videostill. Courtesy Passion Pictures. 
Figure 6: Movie Poster: Kevin Macdonald. One Day in September. 1999. Web. 13 March 2013. Digital Image. http:// en.wikipedia.org/wiki/File:One_Day_in_ September_Cinema_Poster.jpg

Figure 7: Cover page. Der Spiegel. Geheimakte Olympia. 30, 23. July 2012.

Figure 8: Christoph Draeger. Black September. 2002. Synchronized two-channel video installation, DVD 14:30 min. loop, videostill. Courtesy the artist.

Figure 9: Christoph Draeger. Black September. 2002. Synchronized two-channel video installation, DVD 14:30 min. loop, videostill. Courtesy the artist.

Figure 10: Steven Spielberg. Munich. 2005. Filmstill. Courtesy Universal Pictures.

Figure 11: Christoph Draeger. Black September. 2002. Synchronized two-channel video installation, DVD 14:30 min. loop, videostill. Courtesy the artist.

Figure 12: Christoph Draeger. Black September. 2002. Synchronized two-channel video installation, DVD 14:30 min. loop, videostill. Courtesy the artist .
Sebastian Baden was born in 1980 and lives in Bern $(\mathrm{CH})$ and Karlsruhe (D). He is Assistant to Prof. Dr. Beat Wyss in Art History and Media-Theory at the University of Art and Design, Karlsruhe (Staatliche Hochschule für Gestaltung Karlsruhe). Baden studied Painting, Photography and Sculpture at the Academy of Fine Arts Karlsruhe and German Literature at the KIT (Karlsruhe Institut for Technology) from 2001-2007. He was an ERASMUS exchange student with University of Arts in Bern (Hochschule der Künste)/ Switzerland 2004-2005. He then became co-Director of Ferenbalm-GurbrüStation-Exhibitions, Karlsruhe, with Lukas Baden. Since 2007, Baden is a Phd candidate at the University of Art and Design Karlsruhe with a research project on Terrorism in the Arts.

Sebastian Baden est né en 1980 à Berne $(\mathrm{CH})$ et réside actuellement entre sa ville natale et Karlsruhe (G). Il est l'assistant du professeur Beat Wyss qui enseigne l'histoire de l'art et les théories des médias à l'université d'art et de design de Karlsruhe (Staatliche Hochschule für Gestaltung Karlsruhe). Sebastian Baden a étudié la peinture, la photographie, et la sculpture à l'académie des beaux arts de Karlsruhe et la littérature allemande à l'institut de technologies de Karlsruhe (KIT) entre 2001 et 2007. Entre 2004 et 2005 il a participé au programme d'échange ERASMUS avec l'université de Berne (Hochschule der Künste) en Suisse. Il est ensuite devenu co-directeur des expositions à la gallerie Ferenbalm-Gurbrü-Station à Karlsruhe, avec Lukas Baden. Depuis 2007 Baden est inscrit en doctorat à l'université d'art et de design de Karlsruhe. Son projet de recherche porte sur le terrorisme dans les arts. 
Christoph Draeger is a conceptual artist who has been working on themes of disaster and destruction for over 20 years. His projects take form in installation, video, and photobased media to explore issues pertaining to catastrophe and media-saturated culture. Solo exhibitions include Kunsthaus Rapperswil; Kunsthalle Arbon; OK Centrum Linz (w/Heidrun Holzfeind); Kunstmuseum Solothurn; Kunsthaus Zurich (w/Reynold Reynolds); Orchard Gallery, Derry; Roebling Hall, New York; Center of Contemporary Art, Ujazdowskie Castle, Warsaw (PL). Group exhibitions include the Tamya Museum in Mexico City, Whitney Museum, Brooklyn Museum, New Museum, MoMA, P.S.1 (all in New York), Van Abbe Museum in Eindhoven, Carrillo Gil Museum in Mexico City, Centre Pompidou in Paris, Paco das Artes in Sao Paulo, Museum der Moderne in Salzburg, KW Kunstwerke Berlin; Biennals: 55th Venice Biennial, Moscou 2007, Liverpool 2002, Havanna 2000, Kwangju 1997. www.christophdraeger.com
Christoph Draeger est un artiste conceptuel qui travaille depuis plus de vingt ans sur les thèmes du désastre et de la destruction. Ses projets prennent la forme d'installations, de vidéos, et de traitements photographiques afin d'explorer l'existence de la catastrophe dans une culture de saturation médiatique. Ses expositions solo ont pris place aux Kunsthaus Rapperswil; Kunsthalle Arbon; OK Centrum Linz (avec Heidrun Holzfeind); Kunstmuseum Solothurn; Kunsthaus Zurich (w/Reynold Reynolds); Orchard Gallery, Derry; Roebling Hall, New York; Center of Contemporary Art, Ujazdowskie Castle, Warsaw (PL). Il a également pris part à des expositions collectives aux Tamya Museum à Mexico, Whitney Museum, Brooklyn Museum, New Museum, MoMA, P.S.1 (tous à New York), Van Abbe Museum à Eindhoven, Carrillo Gil Museum à Mexico, Centre Pompidou à Paris, Paco das Artes à Sao Paulo, Museum der Moderne à Salzburg, KW Kunstwerke Berlin, ainsi qu'aux Biennales suivantes: 55 th Venice Biennial, Moscou 2007, Liverpool 2002, Havanna 2000, Kwangju 1997. www. christophdraeger.com 